\title{
Genome Size Variation in Malus Species
}

\author{
Monika Höfer ${ }^{1}$ and Armin Meister ${ }^{2}$ \\ ${ }^{1}$ Julius Kühn-Institute, Federal Research Centre for Cultivated Plants, Institute for Breeding Research on Horticultural and Fruit Crops, \\ Pillnitzer Platz 3a, 01326 Dresden, Germany \\ ${ }^{2}$ Leibniz-Institut für Pflanzengenetik und Kulturpflanzenforschung Gatersleben (IPK), Corrensstraße 3, \\ 06466 Gatersleben, Germany
}

Correspondence should be addressed to Monika Höfer, monika.hoefer@jki.bund.de

Received 22 January 2010; Revised 12 March 2010; Accepted 12 March 2010

Academic Editor: Johann Greilhuber

Copyright (C) 2010 M. Höfer and A. Meister. This is an open access article distributed under the Creative Commons Attribution License, which permits unrestricted use, distribution, and reproduction in any medium, provided the original work is properly cited.

\begin{abstract}
The nuclear DNA content for 256 different accessions belonging to 26 primary Malus species and 20 species hybrids was estimated by flow cytometry using propidium iodide. Diploids ranged from 1.245 (M. tschonoskii) to $1.653 \mathrm{pg}$ per 2C nucleus (M. florentina). As our study covered complete phylogenetic and geographic representation, preliminary conclusions between nuclear DNA content and geographical and taxonomic features could be drawn. The data indicated that species found far from the centre of origin in Asia clustered into separate sections and series and possessed higher DNA content. These are M. trilobata and M. florentina the only two species existing in South-East Europe on one hand; M. ioensis and 3x and 4x species M. ×heterophylla, M. ×platycarpa, M. glaucescens, M. angustifolia, M. lancifolia and M. coronaria-in East and Central North America on the other hand. A significantly decreased $1 \mathrm{Cx}$ DNA content was observed with the increase in ploidy for six species.
\end{abstract}

\section{Introduction}

Nuclear DNA amount and genome size are important biodiversity characters, whose study provides a strong unifying element in biology that has both practical and predictive uses [1]. At present, flow cytometry is the method most frequently used for determination of nuclear DNA content in plants. The data are summarized on the homepage of the Royal Botanic Gardens, Kew [2].

The apple, along with many of the important temperate fruit crops, belongs to the Rosaceae or rose family. The genus Malus Mill. comprises 25 to 47 species, depending upon the rank given to several taxa and the acceptance of putative hybrids. Malus classifications differ primarily in the taxonomic level at which infrageneric groupings of species are recognised. Rehder [3-5] proposed a classification system which is now accepted by later authors. Newer reports divided the genus Malus in six [6] or even in seven sections [7]. In China, the centre of origin of the genus Malus, about $80 \%$ of species are native and among them eight newly described species were recently recognized [8]. Most of the species intercross, and since self-incompatibility is common, seeds obtained from a botanic garden are mostly interspecific or intercultivar hybrids. Some taxa formerly listed as species are now classified as cultivated species because they are not known in the wild [6]. Malus is very diverse in morphology in nature, and the species represent a complicated system of ecotypes, forms, and varieties [9].

Most species are diploid $(x=17)$ and cross-pollinated, but Way et al. [10] list Malus coronaria from the American section Chloromeles as apomictic and either triploid or tetraploid. They also note deviations from the normal type in section Euromalus and Sorbomalus: M. sikkimensis, $M$. hupehensis and M. toringoides (apomictic and triploid), $M$. sargenti (apomictic and tetraploid), and M. spectabilis and $M$. baccata (non-apomictic and either diploid or tetraploid).

Arumuganathan and Earle [11] investigated the nuclear DNA content of more than 100 important plant species including Malus. Later, Dickson et al. [12] reported on the DNA content for 17 Malus species and eight cultivated apples, together with other genera of Rosaceae. Tatum et al. [13] determined the nuclear DNA content of various Malus species, hybrids, and cultivated apples included in the national core collection of Malus germplasm in the United States. 


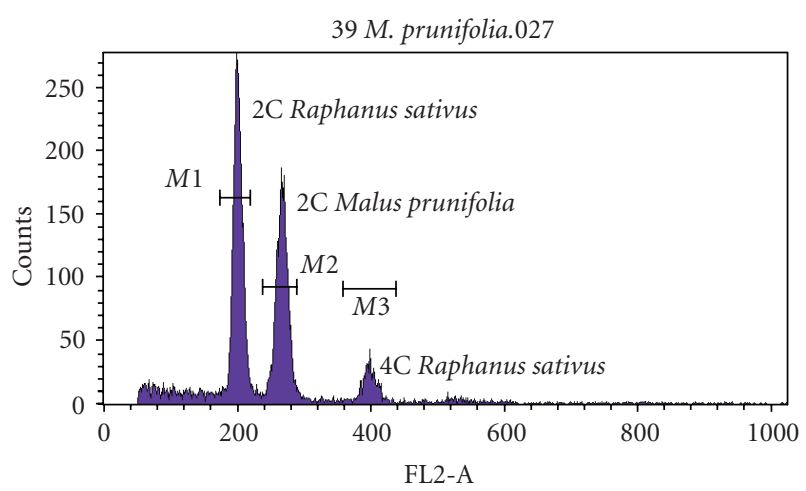

(a)

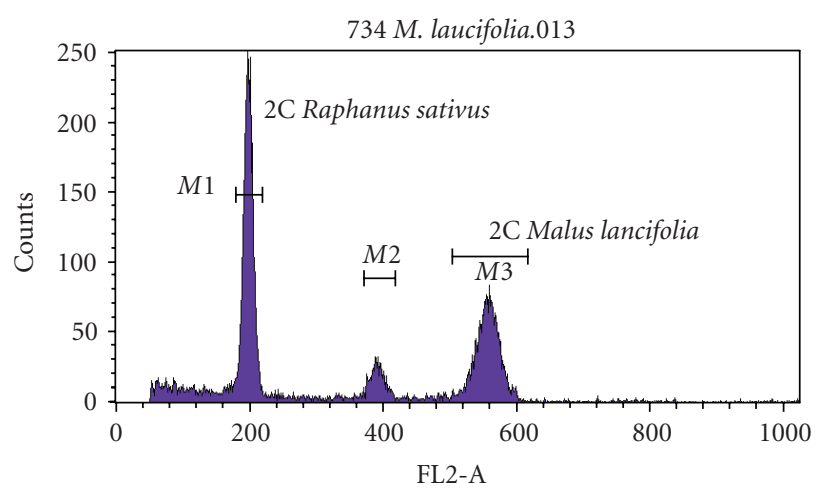

(b)

FIGURE 1: Flow cytometric DNA histograms of nuclei isolated from a diploid (M. prunifolia) and a tetraploid (M. lancifolia) Malus species with the internal standard Raphanus sativus $(1.1 \mathrm{pg} / 2 \mathrm{C})$.

The two main goals of this study were (1) to estimate the variation in the 2C nuclear DNA content for Malus species and of their species hybrids included in the Malus collection in the Institute for Breeding Research on Horticultural and Fruit Crops, Germany; (2) to inspect relationships between nuclear DNA content and geographical features of the taxa. Evaluation of this material representing all ploidy levels will provide an assessment of the level of interspecies variation for nuclear DNA content present in this collection and provides the most comprehensive overview of Malus taxa.

\section{Materials and Methods}

2.1. Experimental Material. Plant materials from 26 primary species and 20 species hybrids, altogether 256 accessions (different individuals) were collected from trees in the orchard of the Malus gene bank of the Institute for Breeding Research on Horticultural and Fruit Crops in Dresden, Saxony, Germany. Species concept and definition of higher rank taxa were based on the works of Rheder [5] and Langenfelds [14]. Seven diploid and four triploid Malus $\times$ domestica cultivars were included. Young leaves were collected in May and June, stored on ice for the transport, and their nuclei were extracted immediately. The number of accessions investigated per species depended on the material available in the collection.

2.2. Nuclei Isolation and Staining. Nuclei were prepared for flow cytometric analysis using a Tris- $\mathrm{MgCl}_{2}$ buffer according to the protocol of Galbraith et al. [15]. The extraction buffer consisted of per litre: $8.83 \mathrm{~g}$ tri-Natriumcitrat-Dihydrat, $9.14 \mathrm{~g} \mathrm{MgCl}_{2} \times 6 \mathrm{H}_{2} \mathrm{O}$, $4.19 \mathrm{~g}$ 3-(N-Morpholino) propanesulfonic acid (MOPS), and 5.0 g Triton $\mathrm{x}$-100. Propidium iodide (PI) was added just before using the buffer $(50 \mu \mathrm{g}$ $\mathrm{ml}^{-1}$ final concentration). Preliminary experiments (not published) determined that the addition of RNAse was required $\left(50 \mu \mathrm{g} \mathrm{ml}^{-1}\right.$ final concentration). Leaf tissues from apple (10 mg, stored on ice) and Raphanus sativus ( $2 \mathrm{mg}$ ) used as an internal standard were co-chopped with a new razor blade in $0.5 \mathrm{~mL}$ extraction buffer in a Petri dish. After dilution with additional $0.5 \mathrm{ml}$ buffer and 1 minute staining time the homogenate was filtered through a $30 \mu \mathrm{m}$ nylon mesh into a labelled test tube. During the preparation of 10 sample replications of each accession the samples were kept on ice. All 10 replications were measured immediately. The nuclear DNA content of radish is reported to be $1.1 \mathrm{pg} / 2 \mathrm{C}$ [16]. Seeds were sown in pots, and plants were grown in a greenhouse. Young healthy leaves of radish plantlets (3rd or 4 th leaf pair) were used for measurements.

2.3. Flow Cytometry. Nuclei were analyzed using a laser Flow Cytometer FACScan (BECTON DICKINSON). PI was excited at $488 \mathrm{~nm}$, and the emission was analysed at $590 \mathrm{~nm}$. A minimum of 10.000 particles per sample were analysed. Mean fluorescence of the apple G1 peak was divided by the fluorescence reading of the G1 peak of the internal standard, multiplied by $1.1 \mathrm{pg} / 2 \mathrm{C}$, and expressed in $\mathrm{pg} / 2 \mathrm{C}$ nucleus.

2.4. Statistical Analysis. For each accession, 10 sample replications were prepared, measured, and analysed. Statistical analyses were performed using SigmaStat Version 3.10, Systat Software 2004. Because the majority of data were not normally distributed, differences in DNA content among the species were tested by nonparametric tests, either by the Mann-Whitney Test (in case of two samples) or by the Kruskal-Wallis Test together with Dunn's Multiple Range Test (in case of more than two samples) to determine significant differences.

\section{Results}

The nuclear DNA content of 256 accessions belonging to 26 primary species and 20 species hybrids of the Malus genus was estimated by flow cytometry using propidium iodide. Significant differences $(P<0.05)$ in $2 \mathrm{C}$ DNA content were detected within the Malus species analysing each ploidy level separately (Table 1). Figure 1 shows typical diploid and tetraploid histograms as analyzed by flow cytometry. The 
TABle 1: Nuclear DNA Content (pg/2C median; 25\% and 75\% value) of Malus species ( $\mathrm{N}^{\circ}$ of accessions used for measurements) with the results of the nonparametric Kruskal-Wallis Test together with Dunn's Multiple Range Test; medians with the same letter are not significantly different at 5\% level. Each ploidy level was analysed separately. Classification was based on the works of Rehder [5] and Langenfelds [14].

\begin{tabular}{|c|c|c|c|c|c|c|c|c|c|c|c|c|}
\hline \multirow{2}{*}{ Species } & \multirow{2}{*}{ Section } & \multirow{2}{*}{ Series } & \multicolumn{4}{|c|}{ Nuclear DNA content (pg/nucleus)* } & \multicolumn{6}{|c|}{ Results of the Kruskal-Wallis Test } \\
\hline & & & $\mathrm{N}^{\circ}$ & Median & $25 \%$ & $75 \%$ & & & & & & \\
\hline Ploidy level $2 \mathrm{x}=34$ & & & & 1.484 & & & & & & & & \\
\hline M. tschonoskii & Docyniopsis & & 1 & 1.245 & 1,150 & 1,283 & $\mathrm{a}$ & & & & & \\
\hline M. yunnanensis & Sorbomalus & Yunnanenses & 2 & 1.337 & 1,320 & 1,350 & a & & & & & \\
\hline M. ombrophila & Sorbomalus & Yunnanenses & 1 & 1.341 & 1,329 & 1,351 & a & $\mathrm{b}$ & & & & \\
\hline M. kansuensis & Sorbomalus & Kansuenses & 6 & 1.365 & 1,350 & 1,384 & $\mathrm{a}$ & $\mathrm{b}$ & & & & \\
\hline M. honanensis & Sorbomalus & Yunnanenses & 1 & 1.378 & 1,276 & 1,413 & $\mathrm{a}$ & $\mathrm{b}$ & & & & \\
\hline M. prattii & Sorbomalus & Yunnanenses & 1 & 1.397 & 1,386 & 1,406 & $\mathrm{a}$ & $\mathrm{b}$ & & & & \\
\hline M. baccata & Euromalus & Baccatae & 16 & 1.440 & 1,430 & 1,467 & & $\mathrm{~b}$ & & & & \\
\hline M. $\times z u m i ~ 2 x$ & Euromalus & Baccatae & 10 & 1.461 & 1,439 & 1,512 & & $\mathrm{~b}$ & c & & & \\
\hline M. $\times$ dawsoniana & Sorbomalus & Kansuenses & 1 & 1.464 & 1,455 & 1,478 & & $\mathrm{~b}$ & c & & & \\
\hline M. fusca & Sorbomalus & Kansuenses & 5 & 1.464 & 1,460 & 1,470 & & $\mathrm{~b}$ & c & & & \\
\hline M. hupehensis $2 \mathrm{x}$ & Euromalus & Baccatae & 2 & 1.466 & 1,451 & 1,475 & & $\mathrm{~b}$ & c & & & \\
\hline M. $\times$ hartwigii & Euromalus & Baccatae & 1 & 1.471 & 1,450 & 1,475 & & $\mathrm{~b}$ & c & & & \\
\hline M. $\times$ adstringensis $2 \mathrm{x}$ & Euromalus & Baccatae & 5 & 1.475 & 1,454 & 1,493 & & $\mathrm{~b}$ & c & & & \\
\hline M. $\times$ moerlandsii & Euromalus & Pumilae & 4 & 1.476 & 1,457 & 1,493 & & $\mathrm{~b}$ & c & & & \\
\hline M. ×purpurea & Euromalus & Pumilae & 7 & 1.484 & 1,467 & 1,493 & & & c & $\mathrm{d}$ & & \\
\hline M. sylvestris & Euromalus & Pumilae & 11 & 1.484 & 1,460 & 1,509 & & & c & $\mathrm{d}$ & & \\
\hline M. $\times$ robusta & Euromalus & Baccatae & 5 & 1.490 & 1,458 & 1,519 & & & c & $\mathrm{d}$ & & \\
\hline M. $\times$ atrosanguinea & Euromalus & Baccatae & 1 & 1.493 & 1,449 & 1,493 & & $\mathrm{~b}$ & c & $\mathrm{d}$ & & \\
\hline M. $\times$ sublobata & Euromalus & Pumilae & 4 & 1.497 & 1,459 & 1,550 & & & c & $\mathrm{d}$ & & \\
\hline M. $\times$ arnoldiana & Euromalus & Baccatae & 3 & 1.499 & 1,470 & 1,529 & & & c & $\mathrm{d}$ & & \\
\hline M. $\times$ asiatica & Euromalus & Pumilae & 4 & 1.500 & 1,470 & 1,514 & & & c & $\mathrm{d}$ & & \\
\hline M. prunifolia & Euromalus & Pumilae & 10 & 1.500 & 1,475 & 1,519 & & & c & $\mathrm{d}$ & & \\
\hline M. sieversii & Euromalus & Pumilae & 6 & 1.501 & 1,482 & 1,513 & & & c & $\mathrm{d}$ & & \\
\hline M. orientalis & Euromalus & Pumilae & 7 & 1.502 & 1,458 & 1,519 & & & c & $\mathrm{d}$ & & \\
\hline M. spectabilis $2 \mathrm{x}$ & Euromalus & Pumilae & 7 & 1.502 & 1,484 & 1,523 & & & c & $\mathrm{d}$ & $\mathrm{e}$ & \\
\hline M. $\times$ scheideckeri & Sorbomalus & Sieboldiane & 3 & 1.507 & 1,479 & 1,530 & & & c & $\mathrm{d}$ & $\mathrm{e}$ & \\
\hline M. floribunda & Sorbomalus & Sieboldiane & 6 & 1.509 & 1,490 & 1,529 & & & c & $\mathrm{d}$ & $\mathrm{e}$ & \\
\hline M. $\times$ domestica $2 \mathrm{x}$ & Euromalus & Pumilae & 8 & 1.514 & 1,487 & 1,530 & & & c & $\mathrm{d}$ & $\mathrm{e}$ & \\
\hline M. $\times$ micromalus & Euromalus & Baccatae & 2 & 1.528 & 1,497 & 1,534 & & & c & $\mathrm{d}$ & $\mathrm{e}$ & \\
\hline M. sieboldii $2 \mathrm{x}$ & Sorbomalus & Sieboldiane & 5 & 1.530 & 1,505 & 1,533 & & & & $\mathrm{~d}$ & $\mathrm{e}$ & \\
\hline M. transitoria & Sorbomalus & Kansuenses & 5 & 1.535 & 1,514 & 1,551 & & & & $\mathrm{~d}$ & $\mathrm{e}$ & \\
\hline M. $\times$ soulardii & Chloromeles & & 4 & 1.564 & 1,512 & 1,588 & & & & $\mathrm{~d}$ & $\mathrm{e}$ & $\mathrm{f}$ \\
\hline M. ioensis $2 \mathrm{x}$ & Chloromeles & & 4 & 1.565 & 1,523 & 1,667 & & & & & $\mathrm{e}$ & $\mathrm{f}$ \\
\hline M. trilobata & Eriolobus & & 3 & 1.638 & 1,621 & 1,667 & & & & & & $\mathrm{f}$ \\
\hline M. florentina & Sorbomalus & Florentinae & 3 & 1.653 & 1,635 & 1,660 & & & & & & $\mathrm{f}$ \\
\hline Ploidy level 3x = 51 & & & & 2.198 & & & & & & & & \\
\hline M. hupehensis 3x & Euromalus & Baccatae & 18 & 2.121 & 2,014 & 2,174 & & & & & & \\
\hline M. sikkimensis $3 \mathrm{x}$ & Euromalus & Baccatae & 7 & 2.165 & 2,148 & 2,180 & $\mathrm{~d}$ & $\mathrm{~b}$ & & & & \\
\hline M. $\times z u m i 3 \mathrm{x}$ & Euromalus & Baccatae & 1 & 2.194 & 2,143 & 2,229 & $\mathrm{a}$ & $\mathrm{b}$ & c & & & \\
\hline M. sieboldii 3x & Sorbomalus & Sieboldiane & 3 & 2.193 & 2,183 & 2,201 & & $\mathrm{~b}$ & c & & & \\
\hline M. $\times$ adstring $3 \mathrm{x}$ & Euromalus & Baccatae & 3 & 2.201 & 2,191 & 2,211 & & $\mathrm{~b}$ & c & & & \\
\hline M. toringoides $3 \mathrm{x}$ & Sorbomalus & Kansuenses & 7 & 2.202 & 2,172 & 2,254 & & $\mathrm{~b}$ & c & & & \\
\hline M. spectabilis $3 \mathrm{x}$ & Euromalus & Pumilae & 1 & 2.206 & 2,195 & 2,216 & & $\mathrm{~b}$ & c & & & \\
\hline M. halliana & Euromalus & Baccatae & 3 & 2.209 & 2,174 & 2,217 & & $\mathrm{~b}$ & c & & & \\
\hline M. komarovii 3x & Sorbomalus & Kansuenses & 5 & 2.232 & 2,210 & 2,261 & & & c & $\mathrm{d}$ & & \\
\hline
\end{tabular}


Table 1: Continued.

\begin{tabular}{|c|c|c|c|c|c|c|c|c|c|c|c|}
\hline \multirow{2}{*}{ Species } & \multirow{2}{*}{ Section } & \multirow{2}{*}{ Series } & \multicolumn{4}{|c|}{ Nuclear DNA content (pg/nucleus)* } & \multicolumn{5}{|c|}{ Results of the Kruskal-Wallis Test } \\
\hline & & & $\mathrm{N}^{\circ}$ & Median & $25 \%$ & $75 \%$ & & & & & \\
\hline M. $\times$ domestica $3 \mathrm{x}$ & Euromalus & Pumilae & 6 & 2.270 & 2,252 & 2,296 & & & $c$ & d & \\
\hline M. sargentii $3 \mathrm{x}$ & Sobomalus & Sieboldiane & 2 & 2.285 & 2,197 & 2,307 & & & & d & \\
\hline M. ioensis $3 \mathrm{x}$ & Chloromeles & & 2 & 2.414 & 2,396 & 2,426 & & & & d & \\
\hline M. coronaria $3 \mathrm{x}$ & Chloromeles & & 3 & 2.428 & 2,183 & 2,462 & & & & d & \\
\hline Ploidy level $4 x=68$ & & & & 3.007 & & & & & & & \\
\hline M. sikkimensis $4 \mathrm{x}$ & Euromalus & Baccatae & 2 & 2.851 & 2,815 & 2,894 & a & & & & \\
\hline M. sieboldii $4 \mathrm{x}$ & Sorbomalus & Sieboldiane & 5 & 2.879 & 2,832 & 2,938 & a & & & & \\
\hline M. komarovii $4 \mathrm{x}$ & Sorbomalus & Kansuenses & 2 & 2.917 & 2,847 & 3,013 & $\mathrm{a}$ & $\mathrm{b}$ & & & \\
\hline M. sargentii $4 \mathrm{x}$ & Sorbomalus & Sieboldiane & 4 & 2.918 & 2,891 & 2,958 & a & $\mathrm{b}$ & & & \\
\hline M. toringoides $4 \mathrm{x}$ & Sorbomalus & Kansuenses & 1 & 2.958 & 2,947 & 2,979 & a & $\mathrm{b}$ & $\mathrm{c}$ & & \\
\hline M. lancifolia & Chloromeles & & 1 & 3.007 & 2,969 & 3,035 & & & $\mathrm{c}$ & d & \\
\hline M. glaucescens & Chloromeles & & 1 & 3.102 & 3,082 & 3,197 & & & & d & $\mathrm{e}$ \\
\hline M. angustifolia & Chloromeles & & 1 & 3.116 & 3,101 & 3,122 & & & $\mathrm{c}$ & d & $\mathrm{e}$ \\
\hline M. ×platycarpa & Chloromeles & & 4 & 3.151 & 3,118 & 3,177 & & & & d & $\mathrm{e}$ \\
\hline M. coronaria $4 \mathrm{x}$ & Chloromeles & & 6 & 3.186 & 3,115 & 3,221 & & & & & $\mathrm{e}$ \\
\hline M. $\times$ heterophylla & Chloromeles & & 1 & 3.193 & 3,167 & 3,216 & & & & & $\mathrm{e}$ \\
\hline \multicolumn{12}{|l|}{ Ploidy level 5x-6x } \\
\hline M. sikkimensis $5 \mathrm{x}$ & Euromalus & Baccatae & 1 & 3.540 & & & & & & & \\
\hline M. sargentii $5 \mathrm{x}$ & Sorbomalus & Sieboldiane & 1 & 3.874 & & & & & & & \\
\hline M. sargentii $5 \mathrm{x}-6 \mathrm{x}$ & Sorbomalus & Sieboldiane & 1 & 4.286 & & & & & & & \\
\hline
\end{tabular}

* Estimation based on propidium iodide staining by using the internal standard radish (1.1 pg/2C).

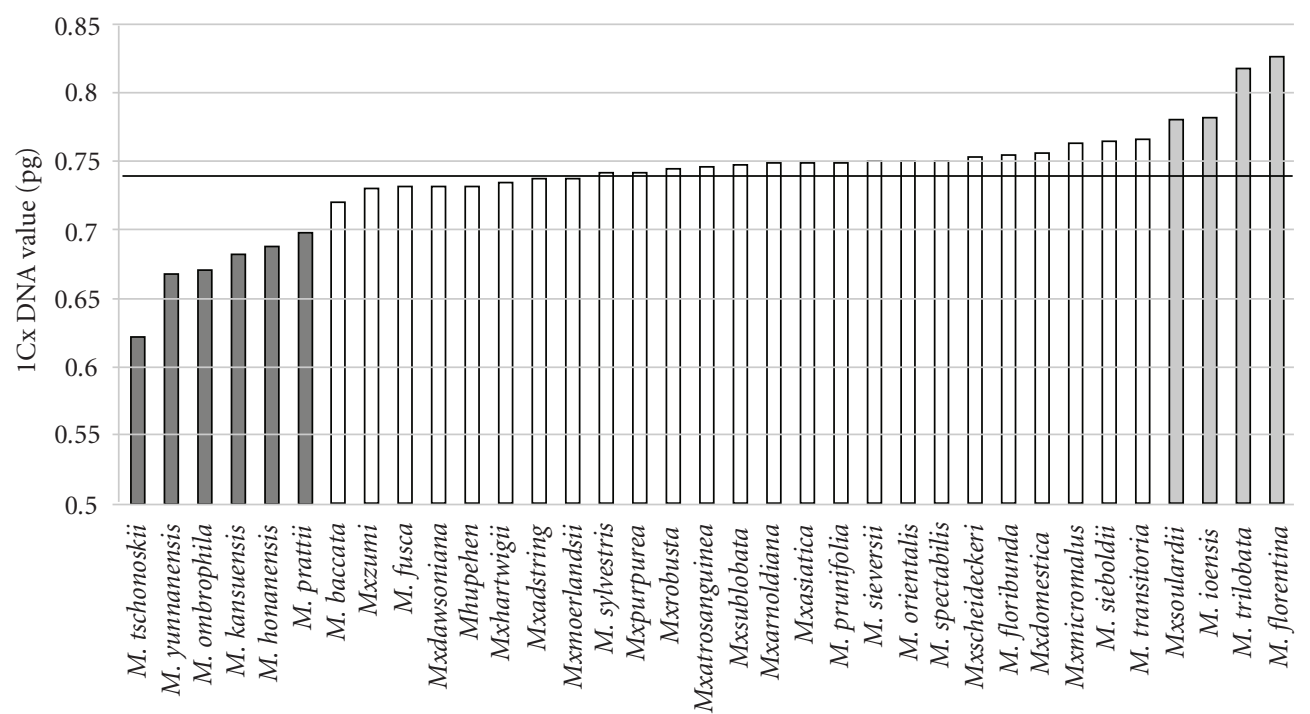

Figure 2: 1CX DNA-values (medians) of the investigated diploid Malus species. Black line represents the median (0.742 pg) of all 34 investigated diploid Malus species. Malus species having 1Cx DNA-values more than 5\% below the median are marked dark grey; species having 1Cx DNA-values higher than 5\% above the median are marked light grey. The detailed statistical data are shown in Table 1.

nuclear DNA content over all ploidy levels (di-, tri-, tetraploids and higher $5 \mathrm{x}-6 \mathrm{x}$ ) ranged from 1.245 to $4.286 \mathrm{pg}$ per nucleus (Table 1).

Among the diploids, the difference between the species with the lowest (Malus tschonoskii-1.245 pg per nucleus) and the highest diploid value (Malus florentina-1.653) was $0.408 \mathrm{pg}(=1.328$-fold $)$ with a median DNA content of
$1.484 \mathrm{pg}$ per nucleus. The median of the cultivated apple (M. $\times$ domestica $2 \mathrm{x})$ determined by measurement of seven cultivars was $1.514 \mathrm{pg}$ per nucleus.

Figure 2 demonstrates the 1Cx DNA values of the 34 investigated diploid Malus species. Six primary species ( $M$. tschonoskii; M. yunnanensis; M. ombrophila; M. kansuensis; $M$. honanensis; $M$. prattii) were characterized by a value 
TABle 2: 1CX-values (*Median) of Malus species demonstrating different ploidy levels. For statistical analysis, differences among the levels were tested by non-parametric tests: either by the Mann-Whitney Test (in case of 2 levels) or by the the Kruskal-Wallis Test together with Dunn's Multiple Test (in case of more than 2 levels). Species with the same letter are not significantly different at $5 \%$ level.

\begin{tabular}{|c|c|c|c|c|}
\hline & $x=2$ & $x=3$ & $x=4$ & $x=5$ \\
\hline M. ioensis & $0.782 \mathrm{a}$ & $0.805 \mathrm{a}$ & & \\
\hline M. coronaria & & $0.809 a$ & $0.796 a$ & \\
\hline M. sargentii & & $0.762 \mathrm{a}$ & $0.730 \mathrm{~b}$ & $0.775 a$ \\
\hline M. sieboldii & $0.765 a$ & $0.730 \mathrm{~b}$ & $0.720 \mathrm{~b}$ & \\
\hline M. $\times$ domestica & $0.757 \mathrm{a}$ & $0.757 \mathrm{a}$ & & \\
\hline M. spectabilis & $0.751 \mathrm{a}$ & $0.735 b$ & & \\
\hline M. komarovii & & $0.744 a$ & $0.729 \mathrm{a}$ & \\
\hline M. toringoides & & $0.734 \mathrm{a}$ & $0.739 a$ & \\
\hline M. $\times$ adstringensis & $0.738 \mathrm{a}$ & $0.733 \mathrm{~b}$ & & \\
\hline M. hupehensis & $0.732 \mathrm{a}$ & $0.707 b$ & & \\
\hline M. $\times z u m i$ & $0.731 \mathrm{a}$ & $0.732 \mathrm{a}$ & & \\
\hline M. sikkimensis & & $0.722 \mathrm{a}$ & $0.712 b$ & $0.708 \mathrm{~b}$ \\
\hline
\end{tabular}

* Estimation based on propidium iodide staining by using the internal standard radish (1.1 pg/2C).

more than 5\% below the $1 \mathrm{Cx}$ median (Figure 2-dark grey marked columns). M. ionensis, the only diploid species existing in East and Central North America, its species hybrids $M$. ×soulardii, M. trilobata, and M. florentina, the only two species existing in South-East Europe, with the highest nuclear DNA content of the diploid species were characterized by a value higher than $5 \%$ above the $1 \mathrm{Cx}$ median of the diploid species (Figure 2-light grey marked columns). 25 species including 17 species hybrid demonstrated 1Cx DNA contents in the interval from $-5 \%$ to $+5 \%$ of the $1 \mathrm{Cx}$ median of the diploid species.

The nuclear DNA content of triploids varied between $2.121 \mathrm{pg}$ and $2.428 \mathrm{pg}$ per nucleus with a median of $2.198 \mathrm{pg}$. Triploids are documented in 13 species in the present collection. Only $M$. halliana exists as triploid accession alone. The tetraploids varied from 2.851 to $3.193 \mathrm{pg}$ per nucleus with a median DNA content of 3.007 pg per nucleus. They were found in 11 species, five of them (M. ×heterophylla, M. ×platycarpa, M. glaucescens, $M$. angustifolia, and $M$. lancifolia) exist at the tetraploid level only. Three accessions were detected at the pentaploid and hexaploid levels.

Twelve species demonstrated accessions at different ploidy levels (Table 2). Three species contain accessions in three ploidy levels: $M$. sargentii and $M$. sikkimensis $(3 \mathrm{x}, 4 \mathrm{x}$, and $5 \mathrm{x})$ and Malus sieboldii $(2 \mathrm{x}, 3 \mathrm{x}$, and $4 \mathrm{x})$. According to the statistical analysis six of 12 species containing two or three ploidies demonstrated significant differences between the calculated 1Cx DNA contents (= monoploid genome size) of the different ploidy levels within these species (Table 2). For these six species an increase in ploidy results in a decrease in the $1 \mathrm{Cx}$ DNA content (M. sargentii; $M$. sieboldii; $M$. spectabilis; M. ×adstringensis; M. hupehensis; M. sikkimensis). The intraspecific variation of each species was expressed by the $25 \%$ and $75 \%$ values of the median calculated by the nonparametric Kruskal-Wallis One Way Analysis of Variance on Ranks (Table 1).

\section{Discussion}

Estimation of nuclear DNA content is one of the important applications of flow cytometry and a reliable and efficient method for characterization of plant nuclear DNA content. Nuclear DNA content represents an important biodiversity character with fundamental biological significance [17]. Studies on nuclear DNA content within Malus of the Rosaceae family were reported by Dickson et al. [12] and Tatum et al. [13]. The present study including 26 primary species and 20 species hybrids demonstrates the most comprehensive investigation of the genus Malus. The data presented provides a nearly complete geographic and phylogenetic representation (lacking four primary species).

Comparing the literature data two aspects have to be considered. First, in contrast to the above-mentioned literature based on one accession (individual) per species, the data presented here are the results of the investigation and analysis of more accessions of each species depending on the material available in the Malus collection of the Institute for Breeding Research on Horticultural and Fruit Crops. Second, Greilhuber et al. [18] considered the choice of a standard as critical for flow cytometric determination of DNA content and recommended that the standard used should have DNA values close to, but not overlapping, the $2 \mathrm{C}$ and $4 \mathrm{C}$ peaks of the target species. Price et al. [19] demonstrated that plant DNA data were more reliable when the internal standard was a plant, and nuclei from both the internal standard and the experimental plant were isolated and stained together to reduce any potential technical variation. For this reason the chosen internal standard for this experiment was radish with a nuclear DNA content of $1.1 \mathrm{pg}$ [16]. Based on the optimized method for the present experiments in which histograms with coefficients of variation (CVs) of both standard and sample below 3 to $4 \%$ were obtained, the internal standard Raphanus sativus was used for the whole spectrum of ploidy 
levels. For further experiments, the application of at least two internal standards bordering the diploid and the tetraploid levels of Malus is planned. Dickson et al. [12] used for the Malus experiments chicken erythrocytes nuclei that were previously fixed and stained, with a nuclear DNA content of $2.33 \mathrm{pg}$ DNA per nucleus. Tatum et al. [13] co-chopped experimental apple leaves together with maize (5.35 pg DNA per nucleus). The present data differed in average by $2 \%$ from the corresponding species analysed by Dickson et al. [12]. A bigger difference exists to the data of Tatum et al. [13] whereas variations in both directions occurred. Tatum et al. [13] have already mentioned their differences to the former data of Dickson et al. [12]. The variation in nuclear DNA content between the lowest (M. tschonoskii) and the highest diploids ( $M$. trilobata) was 0.408 pg corresponding to the data of Dickson et al. [12] investigating the same species and represents $27.5 \%$ of the median DNA content for diploid species. This variation within a ploidy level for the genus Malus is rather small when compared to other genera. Comparable studies investigating species within a genus demonstrated 1.7-fold difference of 2C DNA content in 34 Central European diploid species of Cirsium [20], while fourfold difference in DNA content was reported among 25 diploid species of Lactuca [21] and 23 Trifolium species [22]. Our investigations in Pyrus using 17 different species demonstrated only a difference of $0.067 \mathrm{pg}$ (data not published). For analyzing intraspecific variation of each species (Table 1) more detailed investigations using adequate numbers of accession per species are necessary. Bennett et al. [23] characterized anthocyanins as a potential cause of significant error, inhibitor for propidium iodide DNA staining, and finally for genome size estimations. Elaborating the method of flow cytometric analysis in Malus special attention was given to the release of phenolics known as of ubiquitous distribution in Rosaceae. Based on the described optimized method for the apple material no changes of the DNA fluorescence were observed measuring the same sample in different time intervals in contrast to investigations done with Pyrus (data not published).

Previously, Schuster and Büttner [24] investigated chromosome numbers of many accessions (individuals) from the same Malus wild species collection in Dresden and reported different ploidy levels within eight species. They suggested that differences in ploidy in the same species can be attributed to frequent hybridization within the genus Malus. This hypothesis is supported by the large number of species hybrids available compared to the primary species (Figure 2). According to Ellstrand et al. [25], hybridization occurs most frequently in those genera characterized by a perennial habit, out crossing breeding system, and reproductive modes that are able to stabilize genetic hybridity. The present data of nuclear DNA content confirmed the results of chromosome counting by Schuster and Büttner [24]. By increasing the number of investigated accessions different ploidy levels could be determined in four additional Malus species. Comparing the literature data of Malus expressing different ploidy levels within species [10, 12, 13] Malus komoravii was described as tri- and tetraploid for the first time. The seeds for these accessions originated from in situ locations.
For a detailed analysis between nuclear DNA contents of accessions with different ploidy levels within the same species, the 1Cx DNA content was calculated of all accessions per ploidy and species (Table 2). 12 species demonstrated different ploidies. According to the statistical analysis (differences among the levels tested by non-parametric tests) the $1 \mathrm{Cx}$ DNA content becomes significantly lower with increasing ploidy level in six species (M. sargentii; $M$. sieboldii; M. spectabilis; $M$. ×adstringensis; $M$. hupehensis; $M$. sikkimensis). Leitch and Bennett [26] summarized a largescale study of genera and families and concluded that (i) mean 1C DNA amount did not increase in direct proportion with ploidy, and (ii) mean DNA amount per basic genome tended to decrease with increasing ploidy. It was suggested that the loss of DNA following polyploidy formation, or genome downsizing, may be a widespread phenomenon of considerable biological significance. Molecular investigations of plant nuclear DNA content have shown that most genome size variability is associated with differences in repetitive DNA content, and in all plants investigated, the most significant contributions to genome size are due to a class of mobile DNA called retroelements or retrotransposons [27]. In the present results four primary species and two species hybrids (including Malus $\times$ domestica) exhibit no genome downsizing in polyploids.

Bennett [28] suggested that interspecific variation in DNA content has adaptive significance, and it is correlated with the environment and geographical distribution. Malus species originated from several parts of the world and are geographically distributed from the 1 st to the 5 th climatic zone [29]. According to Tatum et al. [13], triploids and higher polyploids Malus are found mainly in the colder (2nd and 3rd) climatic zones.

The present comprehensive investigation of 26 primary species and 20 species hybrids allows preliminary conclusions concerning the DNA content and the geographical distribution of Malus species and the taxonomical classification (Table 1 and Figure 2). The six primary species ( $M$. tschonoskii; M. yunnanensis; M. ombrophila; M. kansuensis; M. honanensis; $M$. prattii) characterized by a value more than $5 \%$ below the $1 \mathrm{Cx}$ median (Figure 2) originated all from East and Central Asia, the centre of origin of the Malus genus and represent the section Docyniopsis $(M$. tschonoskii) and the series Yunnanenses of the section Sorbomalus. Four diploid species representing the highest nuclear DNA content were characterized by a value higher than 5\% above the $1 \mathrm{Cx}$ median (Figure 2): $M$. ionensis and its species hybrid $M . \times$ soulardii. These two species and all other species widespread in East and Central North America (M. ×heterophylla; M. ×platycarpa; M. glaucescens; $M$. angustifolia; M. lancifolia; $M$. coronaria) belong to the section Chloromeles. Species of this section always demonstrated the highest nuclear DNA content in the tri- and tetraploid level, suggesting a common origin (Table 1). Malus trilobata and $M$. florentina, the third and the fourth Malus species characterized by a value higher than $5 \%$ above the $1 \mathrm{Cx}$ median (Figure 2), represent the only two species existing in South-East Europe. Malus trilobata belongs as the only species to the Section Eriolobus, and Malus florentina is the 
only species of the section Sorbomalus series Florentinae. Harris et al. [30] analysed nuclear rDNA and chloroplast DNA sequences and placed Malus trilobata and Malus florentina in the same cluster. The present measurement of the DNA content would support the results of Harris et al. [30]. Qian et al. [7] characterized Malus florentina as a new section Florentinae. 25 species including 17 species hybrids demonstrated 1Cx DNA contents in the interval from $-5 \%$ to $+5 \%$ of the median of the diploid species. All species belong to the Section Euromalus and Sorbomalus, series Sieboldii and Kansusensis, and have native distribution in Asia and Europe with the exception of the species M. fusca spread on the West coast of North America.

On the basis of the present study, it is apparent that species growing far from the centre of origin cluster in separate sections and series and possessed higher DNA content. These are Malus trilobata and Malus florentina the only two species existing in South-East Europe on one hand; $M$. ioensis and $3 \mathrm{x}$ and $4 \mathrm{x}$ species $M$. Xheterophylla, $M$. ×platycarpa, M. glaucescens, M. Angustifolia, M. Lancifolia, and M. coronaria in East and Central America. Bures et al. [20] found a negative correlation in Cirsium with eastern limits of distribution. Further studies should include the four missing species of the section Sorbomalus, series Kansuenses (M. xiaojinesis), and the section Docyniosis (M. doumeri, $M$. melliana, and M. laosensis) to provide a complete analysis of the genus.

\section{References}

[1] M. D. Bennett and I. J. Leitch, "Plant genome size research: a field in focus," Annals of Botany, vol. 95, no. 1, pp. 1-6, 2005.

[2] M. D. Bennett and I. J. Leitch, "Angiosperm DNA C-values databases (release 5.0, December 2004)," http://data.kew.org/ cvalues/homepage.html.

[3] A. Rehder, "New species, varieties and combinations," Journal Arnold Arboretum, vol. 2, pp. 47-58, 1920.

[4] A. Rehder, Manual of the Cultivated Trees and Shrubs, Macmillan, New York, NY, USA, 2nd edition, 1927.

[5] A. Rehder, Bibliography of Cultivated Trees and Shrubs, The Arnold Arboretum of Harvard University, Jamaica Plain, Mass, USA, 1949.

[6] P. H. L. Forsline, "Collection, maintenance, characterization, and utilization of wild apples of central Asia," in Horticultural Reviews Wild Apple and Fruit Trees of Central Asia, J. Janick, Ed., vol. 29, John Wiley \& Sons, New York, NY, USA, 2003.

[7] G.-Z. Qian, L.-F. Liu, and G.-G. Tang, "A new section in Malus (Rosaceae) from China," Annales Botanici Fennici, vol. 43, no. 1, pp. 68-73, 2006.

[8] Z.-Q. Zhou, "The apple genetic resources in China: the wild species and their distributions, informative characteristics and utilisation," Genetic Resources and Crop Evolution, vol. 46, no. 6, pp. 599-609, 1999.

[9] Y. Li, "A critical review of the species and the taxonomy of Malus Mill in the world," Journal of Fruit Science, vol. 13, pp. 63-81, 1996.

[10] R. D. Way, H. S. Aldwinckle, R. C. Lamb, et al., "Apples (Malus)," in Genetic Resources of Temperate Fruit and Nut Crops. International Society of Horticultural Science, J. N. Moore and J. R. Ballington, Eds., pp. 3-62, Wageningen University, Wageningen, The Netherlands, 1990.
[11] K. Arumuganathan and E. D. Earle, "Nuclear DNA content of some important plant species," Plant Molecular Biology Reporter, vol. 9, no. 3, pp. 208-218, 1991.

[12] E. E. Dickson, K. Arumuganathan, S. Kresovich, and J. J. Doyle, "Nuclear DNA content variation within the Rosaceae," American Journal of Botany, vol. 79, pp. 1081-1086, 1992.

[13] T. C. Tatum, S. Stepanovic, D. P. Biradar, A. L. Rayburn, and S. S. Korban, "Variation in nuclear DNA content in Malus species and cultivated apples," Genome, vol. 48, no. 5, pp. 924-930, 2005.

[14] V. Langenfelds, Apple-Trees-Morphological Evolution, Phylogeny, Geography, Systematics, University of Latvia, Riga Zinatne, Latvia, 1991.

[15] D. W. Galbraith, K. R. Harkins, J. M. Maddox, N. M. Ayres, D. P. Sharma, and E. Firoozabady, "Rapid flow cytometric analysis of the cell cycle in intact plant tissues," Science, vol. 220, no. 4601, pp. 1049-1051, 1983.

[16] J. Dolezel, S. Sgorbati, and S. Lucretti, "Comparison of three DNA fluorochrome for flow cytometric estimation of nuclear DNA content in plants," Physiologia Plantarum, vol. 85, pp. 625-631, 1992.

[17] M. D. Bennett, P. Bhandol, and I. J. Leitch, "Nuclear DNA amounts in angiosperms and their modern uses-807 new estimates," Annals of Botany, vol. 86, no. 4, pp. 859-909, 2000.

[18] J. Greilhuber, E. M. Temsch, and J. C. M. Loureiro, "Nuclear DNA content measurement," in Flow Cytometry with Plant Cells, J. Doležel, J. Greilhuber, and J. Suda, Eds., pp. 67-101, Wiley-VCH Verlag GmbH \& Co. KGaA, Berlin, Germany, 2007.

[19] H. J. Price, G. Hodnett, and J. S. Johnston, "Sunflower (Helianthus annuus) leaves contain compounds that reduce nuclear propidium iodide fluorescence," Annals of Botany, vol. 86, no. 5, pp. 929-934, 2000.

[20] P. Bures, Y.-F. Wang, L. Horova, and J. Suda, "Genome size variation in central European species of Cirsium (Compositae) and their natural hybrids," Annals of Botany, vol. 94, no. 3, pp. 353-363, 2004.

[21] I. Doležalova, A. Lebeda, J. Janecek, J. Cihalikova, E. Kristkova, and O. Vranova, "Variation in chromosome numbers and nuclear DNA contents in genetic resources of Lactuca $L$. Species (Asteraceae)," Genetic Resources and Crop Evolution, vol. 49, no. 4, pp. 383-395, 2002.

[22] L. Vizintin and B. Bohanec, "Measurement of nuclear DNA content of the genus Trifolium L. as a measure of genebank accession identity," Genetic Resources and Crop Evolution, vol. 55, no. 8, pp. 1323-1334, 2008.

[23] M. D. Bennett, H. J. Price, and J. S. Johnston, "Anthocyanin inhibits propidium iodide DNA fluorescence in Euphorbia pulcherrima: implications for genome size variation and flow cytometry," Annals of Botany, vol. 101, no. 6, pp. 777-790, 2008.

[24] M. Schuster and R. Büttner, "Chromosome numbers in the Malus wild species collection of the genebank DresdenPillnitz," Genetic Resources and Crop Evolution, vol. 42, no. 4, pp. 353-361, 1995.

[25] N. C. Ellstrand, R. Whitkus, and L. H. Rieseberg, "Distribution of spontaneous plant hybrids," Proceedings of the National Academy of Sciences of the United States of America, vol. 93, no. 10, pp. 5090-5093, 1996.

[26] I. J. Leitch and M. D. Bennett, "Genome downsizing in polyploid plants," Biological Journal of the Linnean Society, vol. 82, no. 4, pp. 651-663, 2004. 
[27] J. L. Bennetzen, J. Ma, and K. M. Devos, "Mechanisms of recent genome size variation in flowering plants," Annals of Botany, vol. 95, no. 1, pp. 127-132, 2005.

[28] M. D. Bennett, "Variation in genomic form in plants and its ecological implications," New Phytologist, vol. 106, supplement 1, pp. 177-200, 1987.

[29] A. Rehder, Manual of Cultivated Trees and Shrubs, MacMillan, New York, NY, USA, 2nd edition, 1940.

[30] S. A. Harris, J. P. Robinson, and B. E. Juniper, "Genetic clues to the origin of the apple," Trends in Genetics, vol. 18, no. 8, pp. 426-430, 2002. 

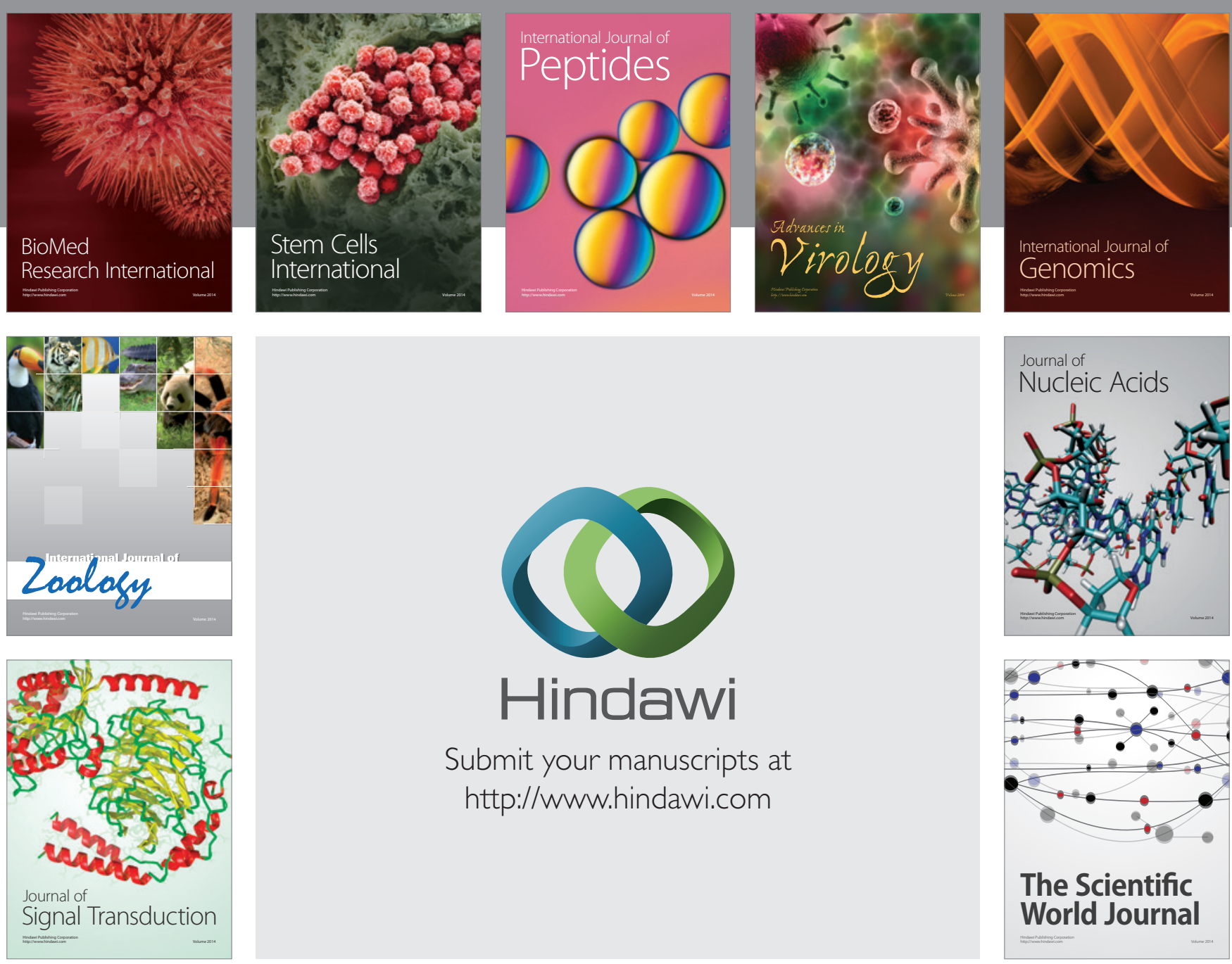

Submit your manuscripts at

http://www.hindawi.com
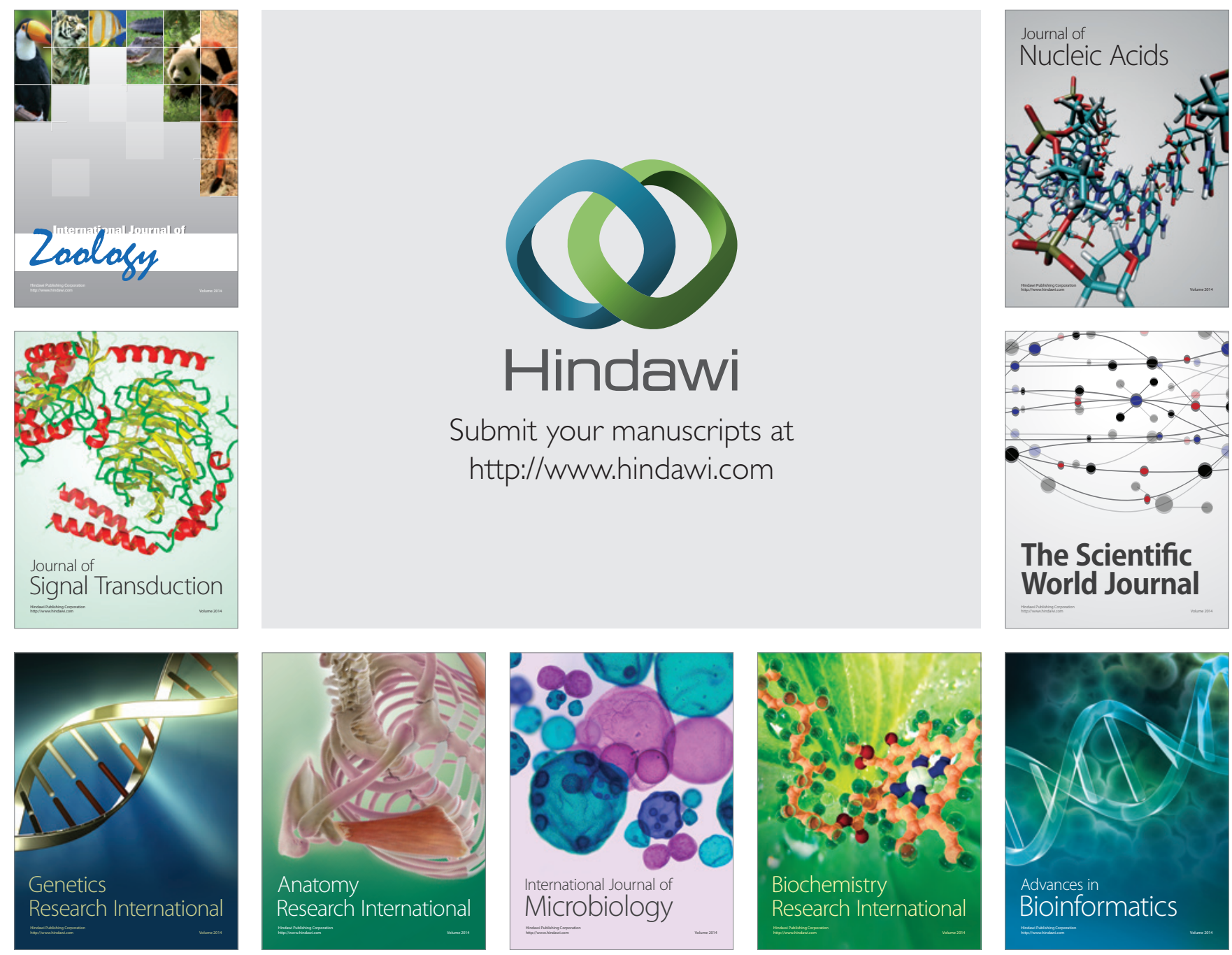

The Scientific World Journal
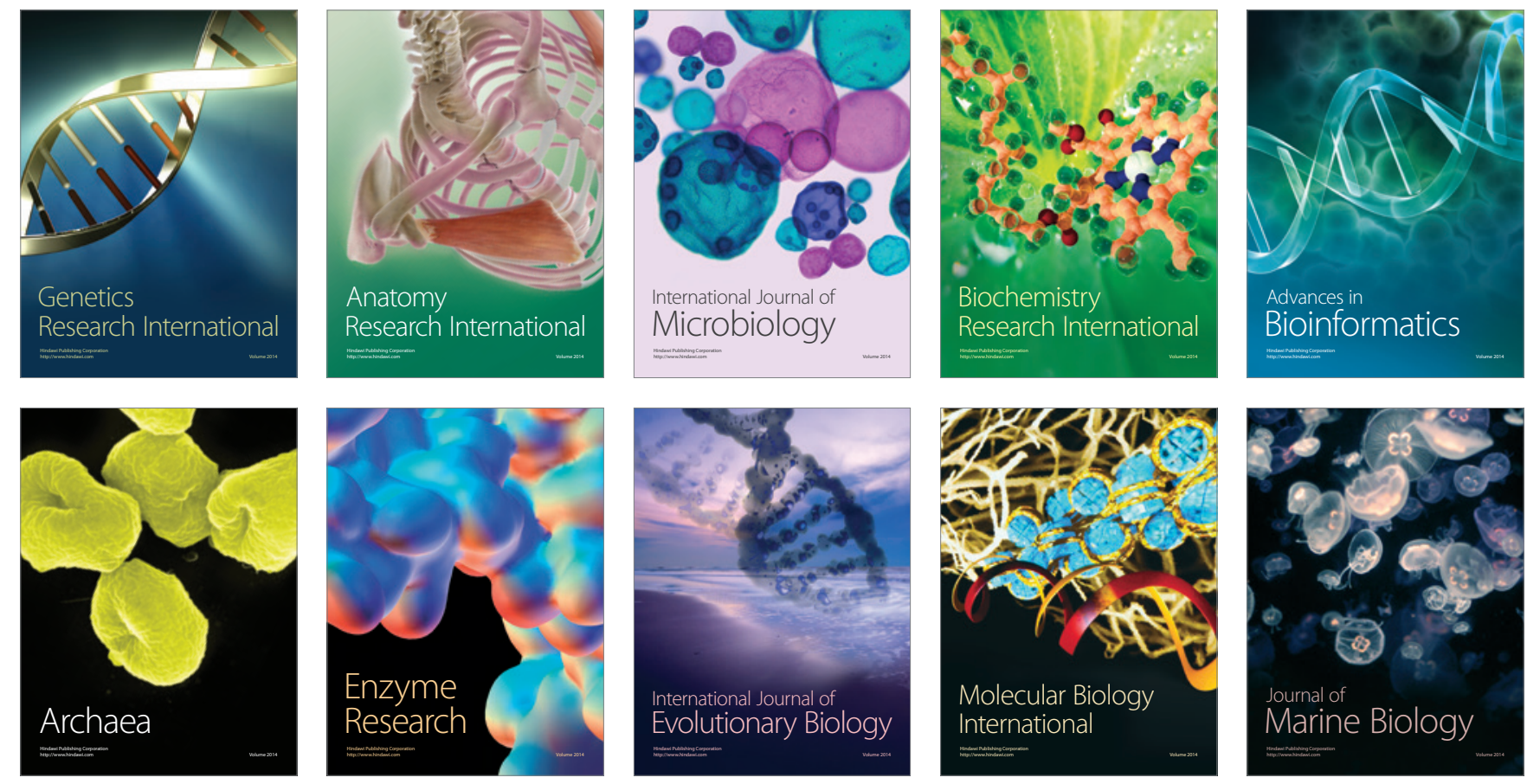